\title{
In silico and in vitro screening of FDA-approved drugs for potential repurposing against tuberculosis
}

\author{
Sridharan Brindha ${ }^{1}$, Jagadish Chandrabose Sundaramurthi ${ }^{2}$, Savariar \\ Vincent ${ }^{1}$, Devadasan Velmurugan ${ }^{3}$, John Joel Gnanadoss ${ }^{1 *}$ \\ ${ }^{1}$ Loyola College, Nungambakkam, Chennai 600034, Tamil Nadu, India \\ ${ }^{2}$ National Institute for Research in Tuberculosis (ICMR), Chetpet, Chennai 600031, \\ Tamil Nadu, India \\ ${ }^{3}$ CAS in Crystallography and Biophysics, University of Madras, Guindy Campus, \\ Chennai - 600025, Tamil Nadu, India
}

\section{*Corresponding Author:}

Dr. John Joel Gnanadoss

Assistant Professor

Department of Biotechnology

Loyola College (University of Madras)

Nungambakkam, Chennai - 600034

Tamil Nadu, India.

Phone: 9840985870

E-mail: joelgna@gmail.com 


\section{ABSTRACT}

\section{Motivation}

Repurposing of known drugs to newer clinical conditions is a promising avenue for finding novel therapeutic applications for tuberculosis.

\section{Methods}

We performed docking-based virtual screening for 1554 known drugs against two of the potential drug targets, namely trpD and coaA of $M$. tuberculosis. In the first round of in silico screening we used rigid docking using Glide and AutoDock Vina. We subjected the consistently ranked drugs for induced-fit docking by these tools against the same target proteins. We performed luciferase reporter phage (LRP) assay to determine the biological activity of five selected drugs against M. tuberculosis.

\section{Results}

We observed lymecycline and cefpodoxime to be active against drug susceptible and drug resistant strains of $M$. tuberculosis. In addition, lymecycline and cefpodoxime showed synergistic activity with rifampin and isoniazid against $M$. tuberculosis.

\section{Conclusion}

Our results suggest that lymecycline and cefpodoxime have potential to be repurposed for the treatment of tuberculosis.

Key words: Tuberculosis; Repurposing; trpD; coaA; Lymecycline; Cefpodoxime. 


\section{INTRODUCTION}

Tuberculosis is the world leading infectious killer disease accounting for 1.3 million deaths and an additional 374000 deaths among HIV-positive people globally in 2016 (WHO 2017). Though tuberculosis can be cured using the currently available drugs, emergence of drug resistant Mycobacterium tuberculosis that results in multiple forms drug resistant TB including multidrug-resistant tuberculosis (MDR-TB) and extensively drug-resistant tuberculosis (XDR-TB) necessitates the discovery of newer therapeutics for the sustained success in the treatment and control of TB. Another difficulty in the management of TB is that minimum of six months is required for the treatment with rifampin, isoniazid, ethambutol and pyrazinamide for first four months and rifampin and isoniazid for next two months. The present situation of the TB treatment certainly demands for much more effective drugs with which we can treat the TB in significantly shorter time and lesser doses.

Conventional process of drug discovery needs about 10 years or more and a big budget of up to billion dollars. In this background, identification of newer therapeutic uses for already known drugs against other diseases, which is referred as repurposing is considered to be a promising avenue in the pharmaceutical industry and academia (Ashburn and Thor 2004). Repurposing is also known by several other terminologies viz., redirecting, repositioning, or reprofiling while identifying new clinical use for molecules which failed during the clinical development stage for its original goal is referred as drug rescue (Langedijk et al., 2015). The scientific principle of repurposing of drugs is that some of the drugs can interact with multiple drug targets. Polypharmacology is a term used to explain the ability of those drugs which can act simultaneously and specifically on multiple targets (Anighoro et al., 2014). Drugs with polypharmacological nature have relatively lower chances for the development of drug resistance since they target multiple drug targets, and show better efficacy compared to drugs with specificity for a single target, especially against advanced-stage diseases (Anighoro et al., 2014; Peters, 2013). However, the polypharmacology differs from the unintended promiscuousity of drugs with unknown target that leads to adverse reactions (Anighoro et al., 2014).

Several drugs have already been successfully repurposed for new diseases, outside the original medical scope. For example, metformin is a commonly used drug for the treatment of type 2 diabetes, now repurposed for cancer (Kasznicki et al., 2014), colesevelam, used for 
hyperlipidemia and repurposed for type-2-diabetes (Finsterer and Frank, 2013), Gabapentin used for epilepsy, now repurposed for neuropathic pain (https://www.drugbank.ca/drugs/DB00996). Drugs which failed to meet the intended purpose can also be repurposed for the treatment of other diseases; for example, zidovudine was first synthesized as a potential anti-cancer agent in 1964 but failed in the cancer treatment, and later in 1984 it was discovered to be active against HIV, and subsequently approved for the treatment in 1987 (Broder, 2010). Recognizing the potential of repurposing of drugs in discovery of newer therapeutic applications especially against diseases that has no drugs to treat or difficult treat, recently government agencies viz., National Institute of Health (USA) and Medical Research Council (UK) established collaborative research with private pharmaceutical industries to promote the repurposing of drugs (Frail et al., 2015).

Several drugs, including, fluroquinolones, clofazimine, meropenem and clavulanate were primarily used for other clinical conditions and now repurposed successfully for treatment of drug resistant forms of TB (Palomino and Martin 2013; Maitra et al., 2015). In addition, several more drugs, to name a few, verapamil (Adams et al., 2011, Gupta et al., 2013 and Adams et al., 2014), statins, (Skerry et al., 2014, Parihar et al., 2014 and Lobato et al., 2014) and metformin (Singhal et al., 2014) have been reported to have potential use in the treatment of TB. These evidences suggest that repurposing of old drugs could be a promising avenue for finding a newer therapeutic drugs for TB.

The genome of $M$. tuberculosis encodes for about 4000 proteins which necessitates scrupulous selection of drug targets for drug discovery. Anthranilate phosphoribosyltransferase ( $\operatorname{trpD}, \mathrm{Rv} 2192 \mathrm{c}$ ) is known to be essential for the optimal growth of M. tuberculosis (Sassetti et al., 2003); it was also demonstrated that the M. tuberculosis auxotrophic for tryptophan (Smith et al., 2001) and the $\operatorname{trpD}$ is involved in the biosynthesis of phenylalanine, tyrosine and tryptophan in M. tuberculosis (http://www.genome.jp/kegg/). Pantothenate kinase (coaA/panK Rv1092c) catalyzes the first step of the universal coenzyme A biosynthetic pathway in M. tuberculosis (Das et al., 2006; Ref:http://www.uniprot.org/uniprot/P9WPA7) and it is an essential gene for the optimal growth of M. tuberculosis (Sassetti et al., 2003; Awasthy et al., 2010) and survival during infection (Sassetti and Rubin, 2003). Further, several bioinformatics analysis revealed trpD (Defelipe et al., 2016; Kushwaha and Shakya 2010; Anishetty et al., 2005) and coaA (Raman et al., 2008; Defelipe et al., 2016) as potential drug targets for M. tuberculosis. Both trpD and 
coaA of M. tuberculosis lack homolog proteins in the human genome. For both of these two proteins, three dimensional structures are available in the Protein Data Bank (Castell et al., 2013 and Chetnani et al., 2010). All these factors encouraged us to select $\operatorname{trpD}$ and $\operatorname{coaA}$ as target proteins against which molecular docking was performed.

In the present study we undertook an effort to prioritize 1554 FDA approved drugs using docking-based virtual screening against two of the potential drug targets and tested some of the prioritized drugs using Luciferase Reporter Phage (LRP) assay against $M$. tuberculosis. We identified cefpodoxime and lymecycline to inhibit drug susceptible and resistant strains of $M$. tuberculosis, and have synergistic role with two of the major antitubercular drugs, rifampin and isoniazid.

\section{METHODS}

\subsection{In silico prioritization of drugs}

A total of 1554 FDA-approved drugs were obtained from DrugBank and virtually screened against two proteins namely anthranilate phosphoribosyltransferase (trpD Rv2192c) and pantothenate kinase (coaA - Rv1092c) of M. tuberculosis using molecular docking with the help of two different docking tools, namely Glide and AutoDock Vina. Rigid body docking algorithm was employed for initial screening. Those drugs which were ranked in top $10 \%$ during rigid-body docking by both Glide and ADV were subjected for induced-fit docking algorithm for further prioritization. Figure 1 and 4 display the workflow of the procedure.

\subsection{In vitro testing by LRP assay against $M$. tuberculosis}

Biological activity of five of the prioritized drugs, namely, cefpodoxime, montelukast, lymecycline, diosmin and carboprost tromethamine were evaluated against $M$. tuberculosis using LRP assay (Kumar et al., 2008; Dusthackeer et al., 2008; Manikkam et al., 2014). Initially, all of the drugs were tested against drug sensitive M. tuberculosis $\mathrm{H} 37 \mathrm{Rv}$ strain at two different concentrations $(20 \mu \mathrm{g} / \mathrm{ml}$ and $100 \mu \mathrm{g} / \mathrm{ml})$. Those drugs which were active in the initial screening were further tested against multidrug-resistant strains of $M$. tuberculosis at four different concentrations $(10,20,50$ and $100 \mu \mathrm{g} / \mathrm{ml})$. Additionally, the active drugs were also tested for synergistic effect with two of the major first-line anti-tubercular drugs rifampin and isoniazid using LRP assay. 


\section{RESULTS}

\subsection{Prioritized drugs against trpD}

We found a total of 26 drugs to be ranked consistently at the end of rigid docking of 1554 FDA approved drugs against $\operatorname{trpD}$. When we subjected these 26 drugs for induced-fit docking against $\operatorname{trp} D, 15$ drugs were observed to be ranked within top 10 ranks by either Glide or AutoDock Vina (Table 1). Experimentally studied compound 2,2'-iminodibenzoic acid in complex with trpD (PDB ID: 3QQS) was used as the control molecule and docked along with $\operatorname{trp} D$. All of the 15 prioritized drugs were found to have better binding affinity score by ADV than the control molecule though only top three ranked molecules were observed to have better Glide score than the control molecule (Table 1). Among these 15 shortlisted drugs, five drugs, namely, acarbose (Glide rank 1 and ADV tank: 2), cefpodoxime $(2,5)$, montelukast $(6,6)$, lymecycline $(7,1)$ and idarubicin $(10,7)$ were ranked consistently within the top 10 drugs by both Glide and ADV.

\subsection{Prioritized drugs against $\operatorname{coaA}$}

When 1554 drugs were screened against coaA of M. tuberculosis, we observed 16 drugs to be ranked consistently within top $10 \%$ in the rigid docking by both Glide and ADV. When we subjected these 16 drugs for induced fit docking by both Glide and ADV, 14 drugs were observed within top 10 ranks (Table 2). Phosphopantothenate (PAZ (N-[(2R)-2hydroxy-3,3-dimethyl-4-(phosphonooxy)butanoyl]- beta-alanine), one of the ligand resolved in complex with coaA (PDB ID: 3AEZ) was used as the control molecule during docking. All of the 14 drugs were observed to have better binding affinity score with coaA than the control molecule, PAZ by ADV while only 8 drugs scored better than PAZ by Glide (Table 2). A total of six drugs namely, flavin adenine dinucleotide (Glide rank: 3, ADV rank: 3), carboprost tromethamine $(4,6)$, montelukast $(5,9)$, paromomycin $(7,5)$, calcium gluceptate $(8,10)$, lymecycline $(9,4)$ were found to be consistently ranked within top 10 drugs by both Glide and ADV.

\subsection{Lymecycline and cefpodoxime inhibit both drug susceptible and resistant strains of}

\section{M. tuberculosis}

Initial in vitro screening for activity was carried out at two different concentrations $(10,20,50$ and $100 \mu \mathrm{g} / \mathrm{ml})$ against drug sensitive strains of $M$. tuberculosis. We found two 
drugs namely cefpodoxime and lymecycline to inhibit M. tuberculosis H37Rv. Cefpodoxime inhibited drug sensitive strains of M. tuberculosis at 20,50 and $100 \mu \mathrm{g} / \mathrm{ml}$ concentrations and lymecycline at 10, 20, 50 and $100 \mu \mathrm{g} / \mathrm{ml}$ concentrations (Table 3). Anti-mycobacterial activity against MDR stains of $M$. tuberculosis was carried out at 20 and $100 \mu \mathrm{g} / \mathrm{ml}$. Both cefpodoxime and lymecycline inhibited MDR strains at 20 and $100 \mu \mathrm{g} / \mathrm{ml}$ concentrations. Other three drugs tested namely, montelukast, diosmin and carboprost tromethamine did not show inhibitory activity against $M$. tuberculosis.

\subsection{Lymecycline and cefpodoxime show synergistic activity with rifampin and isoniazid against M. tuberculosis}

Synergistic role of cefpodoxime and lymecycline against $M$. tuberculosis were determined in the presence of rifampicin and isoniazid (Table 3). Cefpodoxime showed synergistic inhibitory role at $20 \mu \mathrm{g} / \mathrm{ml}$ concentration with rifampin $(2 \mu \mathrm{g} / \mathrm{ml})$ and isoniazid $(0.2 \mu \mathrm{g} / \mathrm{ml})$ against M. tuberculosis. Cefpodoxime $(20 \mu \mathrm{g} / \mathrm{ml})$ showed $89.46 \%$ inhibition of M. tuberculosis when used alone while $99.77 \%$ and $98.39 \%$ when used with rifampin and isoniazid respectively. Similarly, lymecycline alone, in the concentration of $10 \mu \mathrm{g} / \mathrm{ml}$, inhibited $93.47 \%$ of $M$. tuberculosis while $98.35 \%$ and $99.25 \%$ and in the presence of rifampin and isoniazid respectively. These results clearly indicate that cefpodoxime and lymecycline have synergistic role with rifampin and isoniazid against $M$. tuberculosis. Molecular interactions of lymecycline with $\operatorname{trp} D$, cefpodoxime with $\operatorname{trp} D$, and lymecycline with $\operatorname{coaA}$ are displayed in Figures 2, 3 and 5 respectively.

\section{DISCUSSION}

The long duration of time needed for the treatment of TB using the currently available drugs and the emergence drug resistant TB demand for better therapeutic drugs for the successful and sustained control of TB. Given the cost and time required for the development of new drugs using conventional discovery process, recent success in the repurposing of drugs has encouraged researchers to pursue research in this discipline, especially for TB. Since M. tuberculosis encodes for more than 4000 proteins, utmost care should be taken for the selection of target proteins based on which the whole prioritization of drugs is determined. Given the fact that both of the targets selected (trpD and $\operatorname{coa} A$ ) are essential for the optimal growth or survival of M. tuberculosis (Sassetti et al., 2003; Smith et al., 2001; 
Awasthy et al., 2010; Sassetti and Rubin, 2003), molecules used to inhibit these proteins are likely to have therapeutic value for tuberculosis.

The in vitro activity of cefpodoxime observed in this study is further encouraged by the significant uses of other beta-lactam antibiotics, amoxicillin, imipenem and meropenem in the treatment of DR-TB (WHO, 2014). Cefpodoxime is a semi-synthetic cephalosporin and a beta-lactam bactericidal antibiotic which targets penicillin-binding proteins (PBPs) located in the bacterial cytoplasmic membrane of the target bacteria. Beta-lactum antibiotics are used in combination with clavulanate to get protected from the beta-lactamase of $M$. tuberculosis (Ref: Hugonnet et al., 2009). Out observation of cefpodoxime being active against drug sensitive and resistant $M$. tuberculosis strains indicate its potential role in the treatment of TB. Furthermore, synergistic activity of cefpodoxime with rifampicin as well as with isoniazid suggest that cefpodoxime may potentially reduce the time needed for the treatment of TB in combination with a beta-lactamase inhibitor.

Lymecycline is a tetracycline broad-spectrum antibiotic used for the treatment of urinary tract infection, and other bacterial infections such as gonorrhea and chlamydia. Lymecycline known to bind to the $30 \mathrm{~S}$ ribosomal subunit and inhibit protein synthesis (https://www.drugbank.ca/). However, the observation of strong binding of lymecycline with $\operatorname{trpD}$ and coaA and subsequent inhibition of drug sensitive and resistant strains of $M$. tuberculosis in the present study indicates a possible polypharmacology nature of the lymeycline. Further, since lymecycline was found to have synergistic activity with rifampin and isoniazid it may potentially reduce the time needed for the treatment of TB. However, studies in animal models are needed to establish its efficacy against $M$. tuberculosis under in vivo conditions.

Our prioritized drugs becomes significant because a total of 4 of these 29 drugs have already been reported to have activity against $M$. tuberculosis. Among the 15 drugs prioritized against $\operatorname{trpD}$, two drugs namely acarbose (ranked 1 and 2 by Glide and ADV, respectively) and idarubicin (rank: 10 and 7) were reported previously as active against $M$. tuberculosis. For example, acarbose has been reported to inhibit trehalose synthase (treS) of Mycobacterium smegmatis which share $83 \%$ sequence identity with treS of M. tuberculosis (Caner et al., 2013; and Pan et al., 2008). Idarubicin is already known to target bacterial primase $d n a G$, a DNA-dependent RNA polymerase and inhibit $M$. smegmatis (MIC $=0.6$ 
$\mu \mathrm{M})$ and M. tuberculosis $(\mathrm{MIC}=80 \mu \mathrm{M})$ (Gajadeera et al 2015). Similarly, two of the 14 prioritized drugs against $\operatorname{coaA}$, namely paromomycin (rank:7 and 5) and daunorubicin (rank: 2 and 14) were previously reported to have antimycobacterial activity. Particularly, paromomycin was demonstrated to have early bactericidal activity against $M$. tuberculosis (Donald et al., 2000) in a pilot clinical research study in newly diagnosed pulmonary tuberculosis patients (Donald et al., 2000). Daunorubicin was recently demonstrated to inhibit growth of M. tuberulosis and M. smegmatis under in vitro conditions (Gajadeera et al., 2015). Since four of 29 prioritized drugs (acarbose, idarubicin, paromomycin and daunorubicin) have already reported to have potential use for the treatment of $\mathrm{TB}$, especially evidence generated from clinical research for paromomycin (Donald et al., 2000) encourage us to speculate that other drugs prioritized using the same method are likely to have potential activity against $M$. tuberculosis.

\section{Conclusion}

Since 4 out of 25 prioritized drugs are already reported to have potential use against M. tuberculosis using in vitro studies and clinical research, the procedure employed in this study becomes significant, thus, it can be adopted to prioritize drugs for repurposing against any other diseases. Biological activity of lymecycline and cefpodoxime against drug sensitive and drug resistant strains of $M$. tuberculosis and their synergistic role with rifampin and isoniazid suggest that these two drugs have potential for repurposed in the treatment of TB.

\section{ACKNOWLEDGEMENTS}

SB acknowledges sincerely the management of Loyola College, Chennai, India for providing the facility to carry out her Ph.D work. JCS is supported by ICMR-Biomedical Informatics Centre, NIRT, Chennai, India.

Conflict of Interest: none declared. 


\section{REFERENCES}

Adams KN, Szumowski JD, Ramakrishnan L. Verapamil, and its metabolite norverapamil, inhibit macrophage-induced, bacterial efflux pump-mediated tolerance to multiple antitubercular drugs. J Infect Dis. 2014 Aug 1;210(3):456-66.

Adams KN, Takaki K, Connolly LE, Wiedenhoft H, Winglee K, Humbert O, Edelstein PH, Cosma CL, Ramakrishnan L. Drug tolerance in replicating mycobacteria mediated by a macrophage-induced efflux mechanism. Cell. 2011 Apr 1;145(1):39-53.

Anighoro A, Bajorath J, Rastelli G. Polypharmacology: challenges and opportunities in drug discovery. J Med Chem. 2014 Oct 9;57(19):7874-87.

Anishetty S, Pulimi M, Pennathur G. Potential drug targets in Mycobacterium tuberculosis through metabolic pathway analysis. Comput Biol Chem. 2005 Oct;29(5):368-78.

Ashburn TT, Thor KB. Drug repositioning: identifying and developing new uses for existing drugs. Nat Rev Drug Discov. 2004 Aug;3(8):673-83.

Awasthy D, Ambady A, Bhat J, Sheikh G, Ravishankar S, Subbulakshmi V, Mukherjee K, Sambandamurthy V, Sharma U. Essentiality and functional analysis of type I and type III pantothenate kinases of Mycobacterium tuberculosis. Microbiology. 2010 Sep;156(Pt 9):2691-701.

Broder S. The development of antiretroviral therapy and its impact on the HIV-1/AIDS pandemic. Antiviral Res. 2010 Jan;85(1):1-18.

Castell A, Short FL, Evans GL, Cookson TV, Bulloch EM, Joseph DD, Lee CE, Parker EJ, Baker EN, Lott JS. The substrate capture mechanism of Mycobacterium tuberculosis anthranilate phosphoribosyltransferase provides a mode for inhibition. Biochemistry. 2013 Mar 12;52(10):1776-87.

Chetnani B, Kumar P, Surolia A, Vijayan M. M. tuberculosis pantothenate kinase: dual substrate specificity and unusual changes in ligand locations. J Mol Biol. $2010 \mathrm{Jul}$ 9;400(2):171-85.

Das S, Kumar P, Bhor V, Surolia A, Vijayan M. Invariance and variability in bacterial PanK: a study based on the crystal structure of Mycobacterium tuberculosis PanK. Acta Crystallogr D Biol Crystallogr. 2006 Jun;62(Pt 6):628-38.

Defelipe LA, Do Porto DF, Pereira Ramos PI, Nicolás MF, Sosa E, Radusky L, Lanzarotti E, Turjanski AG, Marti MA. A whole genome bioinformatic approach to determine potential latent phase specific targets in Mycobacterium tuberculosis. Tuberculosis (Edinb). 2016 Mar;97:181-92.

Donald PR, Sirgel FA, Kanyok TP, Danziger LH, Venter A, Botha FJ, Parkin DP, Seifart HI, Van De Wal BW, Maritz JS, Mitchison DA. Early bactericidal activity of paromomycin (aminosidine) in patients with smear-positive pulmonary tuberculosis. Antimicrob Agents Chemother. 2000 Dec;44(12):3285-7.

Dusthackeer A, Kumar V, Subbian S, Sivaramakrishnan G, Zhu G, Subramanyam B, Hassan S, Nagamaiah S, Chan J, Paranji Rama N. Construction and evaluation of luciferase reporter 
phages for the detection of active and non-replicating tubercle bacilli. J Microbiol Methods. 2008 Apr;73(1):18-25.

Finsterer J, Frank M. Repurposed drugs in metabolic disorders. Curr Top Med Chem. 2013;13(18):2386-94.

Frail DE, Brady M, Escott KJ, Holt A, Sanganee HJ, Pangalos MN, Watkins C, Wegner CD. Pioneering government-sponsored drug repositioning collaborations: progress and learning. Nat Rev Drug Discov. 2015 Dec;14(12):833-41.

Gajadeera C, Willby MJ, Green KD, Shaul P, Fridman M, Garneau-Tsodikova S, Posey JE, Tsodikov OV. Antimycobacterial activity of DNA intercalator inhibitors of Mycobacterium tuberculosis primase DnaG. J Antibiot (Tokyo). 2015 Mar;68(3):153-7.

Gupta S, Tyagi S, Almeida DV, Maiga MC, Ammerman NC, Bishai WR. Acceleration of tuberculosis treatment by adjunctive therapy with verapamil as an efflux inhibitor. Am J Respir Crit Care Med. 2013 Sep 1;188(5):600-7.

Hugonnet JE, Tremblay LW, Boshoff HI, Barry CE 3rd, Blanchard JS. Meropenemclavulanate is effective against extensively drug-resistant Mycobacterium tuberculosis. Science. 2009 Feb 27;323(5918):1215-8.

Kasznicki J, Sliwinska A, Drzewoski J. Metformin in cancer prevention and therapy. Ann Transl Med. 2014 Jun;2(6):57.

Kumar V, Loganathan P, Sivaramakrishnan G, Kriakov J, Dusthakeer A, Subramanyam B, Chan J, Jacobs WR Jr, Paranji Rama N. Characterization of temperate phage Che12 and construction of a new tool for diagnosis of tuberculosis. Tuberculosis (Edinb). 2008 Nov;88(6):616-23.

Kushwaha SK, Shakya M. Protein interaction network analysis--approach for potential drug target identification in Mycobacterium tuberculosis. J Theor Biol. 2010 Jan 21;262(2):284-94.

Langedijk J, Mantel-Teeuwisse AK, Slijkerman DS, Schutjens MH. Drug repositioning and repurposing: terminology and definitions in literature. Drug Discov Today. 2015 Aug;20(8):1027-34.

Lobato LS, Rosa PS, Ferreira Jda S, Neumann Ada S, da Silva MG, do Nascimento DC, Soares CT, Pedrini SC, Oliveira DS, Monteiro CP, Pereira GM, Ribeiro-Alves M, Hacker MA, Moraes MO, Pessolani MC, Duarte RS, Lara FA. Statins increase rifampin mycobactericidal effect. Antimicrob Agents Chemother. 2014 Oct;58(10):5766-74.

Maitra A, Bates S, Kolvekar T, Devarajan PV, Guzman JD, Bhakta S. Repurposing-a ray of hope in tackling extensively drug resistance in tuberculosis. Int J Infect Dis. 2015 Mar;32:505.

Manikkam R, Venugopal G, Subramaniam B, Ramasamy B, Kumar V. Bioactive Potential of Actinomycetes from Less Explored Ecosystems against Mycobacterium tuberculosis and Other Nonmycobacterial Pathogens. Int Sch Res Notices. 2014 Nov 9;2014:812974. 
Palomino JC, Martin A. Is repositioning of drugs a viable alternative in the treatment of tuberculosis? J Antimicrob Chemother. 2013 Feb;68(2):275-83.

Parihar SP, Guler R, Khutlang R, Lang DM, Hurdayal R, Mhlanga MM, Suzuki H, Marais $\mathrm{AD}$, Brombacher F. Statin therapy reduces the mycobacterium tuberculosis burden in human macrophages and in mice by enhancing autophagy and phagosome maturation. J Infect Dis. 2014 Mar 1;209(5):754-63.

Peters JU. Polypharmacology - foe or friend? J Med Chem. 2013 Nov 27;56(22):8955-71.

Raman K, Yeturu K, Chandra N. targetTB: a target identification pipeline for Mycobacterium tuberculosis through an interactome, reactome and genome-scale structural analysis. BMC Syst Biol. 2008 Dec 19;2:109.

Sassetti CM, Boyd DH, Rubin EJ. Genes required for mycobacterial growth defined by high density mutagenesis. Mol Microbiol. 2003 Apr;48(1):77-84.

Sassetti CM, Rubin EJ. Genetic requirements for mycobacterial survival during infection. Proc Natl Acad Sci U S A. 2003 Oct 28;100(22):12989-94. Epub 2003 Oct 20.

Singhal A, Jie L, Kumar P, Hong GS, Leow MK, Paleja B, Tsenova L, Kurepina N, Chen J, Zolezzi F, Kreiswirth B, Poidinger M, Chee C, Kaplan G, Wang YT, De Libero G. Metformin as adjunct antituberculosis therapy. Sci Transl Med. 2014 Nov 19;6(263):263ra159.

Skerry C, Pinn ML, Bruiners N, Pine R, Gennaro ML, Karakousis PC. Simvastatin increases the in vivo activity of the first-line tuberculosis regimen. J Antimicrob Chemother. 2014 Sep;69(9):2453-7.

Smith DA, Parish T, Stoker NG, Bancroft GJ. Characterization of auxotrophic mutants of Mycobacterium tuberculosis and their potential as vaccine candidates. Infect Immun. 2001 Feb;69(2):1142-50.

WHO 2014. Companion handbook to the WHO guidelines for the programmatic management of drug-resistant tuberculosis, World Health Organization 2014

WHO 2017. Global tuberculosis report, World Health Organization 2017 


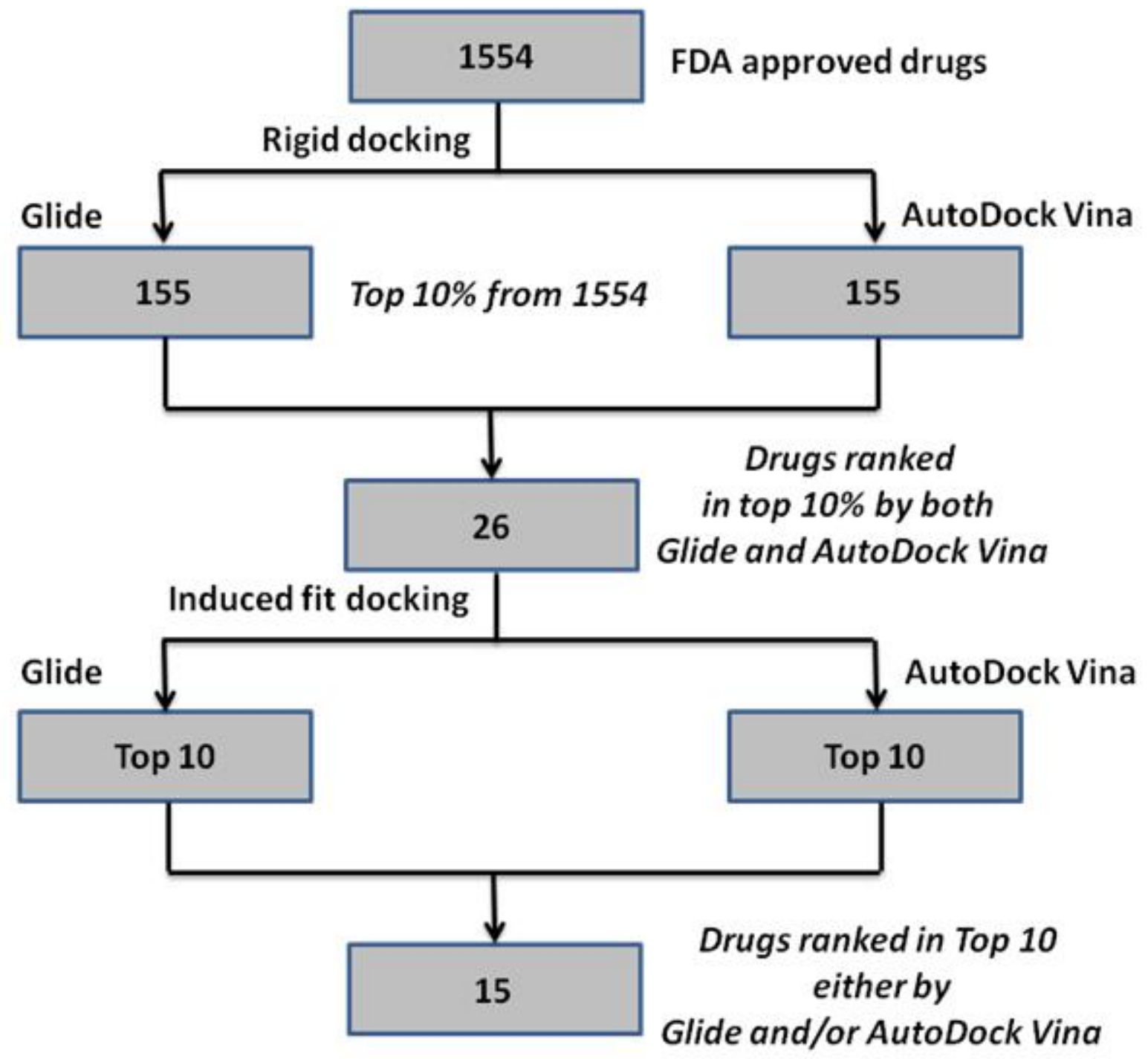

Figure 1: Prioritization of 1554 known drugs using virtual screening against $\operatorname{trpD}$ of $M$. tuberculosis. 
Table 1. Prioritized drugs which show strong binding interactions with $\operatorname{trpD}$ of $M$. tuberculosis

\begin{tabular}{|c|c|c|c|c|c|c|c|c|c|}
\hline $\begin{array}{l}\text { S. } \\
\text { No. }\end{array}$ & $\begin{array}{l}\text { DrugBank } \\
\text { ID }\end{array}$ & Drug name & Primary use & Glide score & $\begin{array}{l}\text { Glide } \\
\text { Rank }\end{array}$ & $\begin{array}{l}\text { ADV } \\
\text { Binding } \\
\text { Affinity }\end{array}$ & $\begin{array}{l}\text { ADV } \\
\text { Rank }\end{array}$ & $\begin{array}{c}\text { RMSD } \\
\left(\mathbf{A}^{\mathbf{0}}\right)\end{array}$ & $\begin{array}{l}\text { Amino acids of } \operatorname{trpD} \\
\text { interacting with drugs }\end{array}$ \\
\hline 1 & DB00284 & Acarbose & $\begin{array}{l}\text { For treatment and management } \\
\text { of diabetes type II }\end{array}$ & -15.4839 & 1 & -21.5 & 2 & 0.089 & $\begin{array}{l}\text { PRO180, ASN138, ARG193, } \\
\text { ALA190, GLY146, SER142, THR108, } \\
\text { ARG139, HIS183 }\end{array}$ \\
\hline 2 & DB01416 & $\begin{array}{l}\text { Cefpodoxim } \\
\text { e }\end{array}$ & Treatment of bacterial infections & -14.2645 & 2 & -19.6 & 5 & 0.086 & $\begin{array}{l}\text { ARG193, ASN138, ARG194, } \\
\text { PRO180, HI136, ARG139 }\end{array}$ \\
\hline 3 & DB00326 & $\begin{array}{l}\text { Calcium } \\
\text { Gluceptate }\end{array}$ & $\begin{array}{l}\text { For treatment of mild } \\
\text { hypocalcemia due to neonatal } \\
\text { tetany }\end{array}$ & -14.04 & 3 & -18.4 & 13 & 0.083 & $\begin{array}{l}\text { ASN138, ARG194, ARG193, } \\
\text { ARG139 }\end{array}$ \\
\hline 4 & DB04868 & Nilotinib & $\begin{array}{l}\text { Treatment for chronic } \\
\text { myelogenous leukemia }\end{array}$ & -9.53503 & 4 & -17.6 & 17 & 0.1 & ARG193, ASN138 \\
\hline 5 & DB00410 & Mupirocin & $\begin{array}{l}\text { Treatment of Gram-positive } \\
\text { bacterial infections }\end{array}$ & -9.21598 & 5 & -18 & 16 & 0.129 & $\begin{array}{l}\text { ARG194, ARG193, ASN138, } \\
\text { ALA140, ARG139, ARG187 }\end{array}$ \\
\hline 6 & DB00471 & Montelukast & Treatment of asthma & -9.14588 & 6 & -19.1 & 6 & 0.102 & ARG194, ASN138, PRO180 \\
\hline 7 & DB00256 & Lymecycline & $\begin{array}{l}\text { For the treatment of infections } \\
\text { and to treat acne }\end{array}$ & -8.73819 & 7 & -23.1 & 1 & 0.749 & $\begin{array}{l}\text { ARG194, ARG193, ALA140, } \\
\text { ASN203, GLY197, VAL198, ALA141 }\end{array}$ \\
\hline 8 & DB00116 & $\begin{array}{l}\text { Tetrahydrofo } \\
\text { lic acid }\end{array}$ & For nutritional supplementation & -8.6072 & 8 & -17.1 & 21 & 0.746 & $\begin{array}{l}\text { ARG194, ARG193, ALA294, } \\
\text { ALA141, SER142, ASN203, VAL198 }\end{array}$ \\
\hline 9 & DB08957 & $\begin{array}{l}\text { Hexoprenali } \\
\text { ne }\end{array}$ & $\begin{array}{l}\text { Used as a bronchodilator, } \\
\text { antiasthmatic, and tocolytic } \\
\text { agent }\end{array}$ & -8.01852 & 9 & -17 & 23 & 0.755 & $\begin{array}{l}\text { ARG194, ARG193, ASN203, } \\
\text { SER142, GLY197 }\end{array}$ \\
\hline 10 & DB01177 & Idarubicin & $\begin{array}{l}\text { For the treatment of acute } \\
\text { myeloid leukemia (AML) in } \\
\text { adults }\end{array}$ & -7.24451 & 10 & -19 & 7 & 0.746 & $\begin{array}{l}\text { ARG193, ARG194, ALA140, } \\
\text { ARG139, ALA141, VAL198, } \\
\text { GLY197 }\end{array}$ \\
\hline 11 & DB06813 & Pralatrexate & $\begin{array}{l}\text { Treatment of relapsed or } \\
\text { refractory peripheral T-cell } \\
\text { lymphoma }\end{array}$ & -4.47393 & 18 & -18.7 & 10 & 0.754 & ALA140, ARG139, ARG181 \\
\hline 12 & DB01328 & Cefonicid & Treatment of bacterial infections & -4.42794 & 19 & -19.8 & 4 & 0.755 & ARG139 \\
\hline 13 & DB01411 & Pranlukast & $\begin{array}{l}\text { Used as an adjunct to the } \\
\text { standard therapy of inhaled } \\
\text { steroids with inhaled long- } \\
\text { and/or short-acting beta- }\end{array}$ & -4.00493 & 22 & -20 & 3 & 0.751 & ARG194, ARG187 \\
\hline
\end{tabular}




\begin{tabular}{|c|c|c|c|c|c|c|c|c|c|}
\hline & & & agonists. & & & & & & \\
\hline 14 & DB08909 & $\begin{array}{l}\text { Glycerol } \\
\text { Phenylbutyr } \\
\text { ate }\end{array}$ & $\begin{array}{l}\text { Treatment of urea cycle } \\
\text { disorders (UCDs) }\end{array}$ & -2.48438 & 25 & -18.9 & 8 & 0.749 & ARG194, HIS188, ARG58, ARG139 \\
\hline 15 & DB01301 & $\begin{array}{l}\text { Rolitetracycl } \\
\text { ine }\end{array}$ & $\begin{array}{l}\text { Tetracycline antibiotic for the } \\
\text { treatment of infections }\end{array}$ & -1.84438 & 26 & -18.9 & 9 & 0.76 & ARG187 \\
\hline & $\begin{array}{l}\text { DB ligand ID: } \\
17 \mathrm{C}(3 \mathrm{QQS})\end{array}$ & $\begin{array}{l}2,2^{\prime}- \\
\text { iminodibenz } \\
\text { oic acid }\end{array}$ & Substrate (control) & -9.7798 & & -7.1 & & 1.295 & ASN138, ARG193, ARG194, HIS183 \\
\hline
\end{tabular}

Amino acids in bold are from the active site of the trpD. 


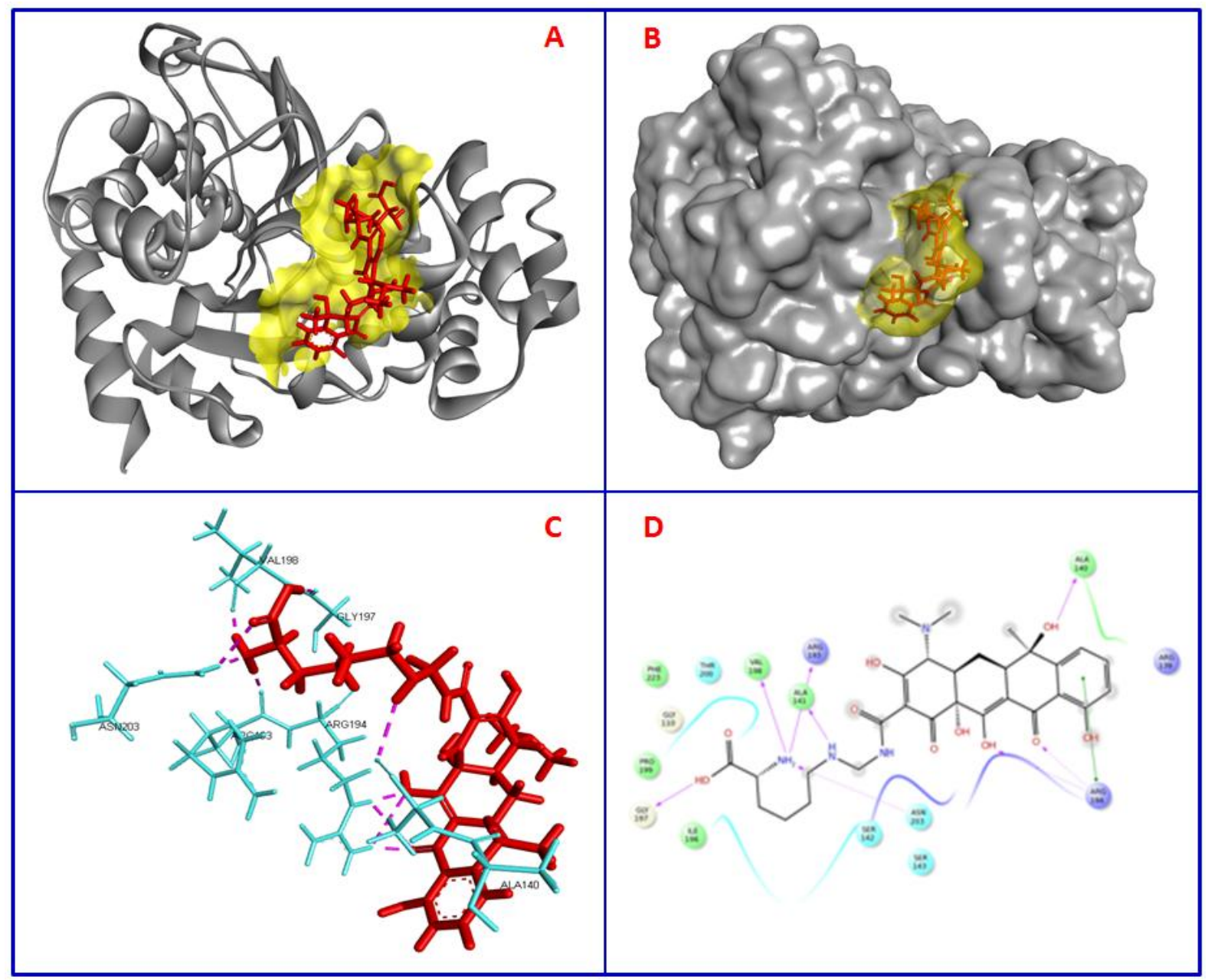

Figure 2: Effective binding of lymecyline in the active site of the trpD of $M$. tuberculosis. Fig 2A shows the trpD in solid ribbon form (grey in color) while lymecycline is showed in red stick form. The active site of the protein is shown as surface (yellow ). Fig $2 \mathrm{~B}$ shows the overall surface of the $\operatorname{trp} D$ and lymecycline with the grey color for $\operatorname{trpD}$ and transparent yellow for lymecycline (stick form). Fig $2 \mathrm{C}$ shows the interacting amino acids of $\operatorname{trpD}$ in the cyan color while the drug lymecycline is displayed in red color stick form with hydrogen bonds in pink color dotted lines. Fig2D displays the interactions between the $\operatorname{trp} D$ and lymecycline in two dimensional view. 


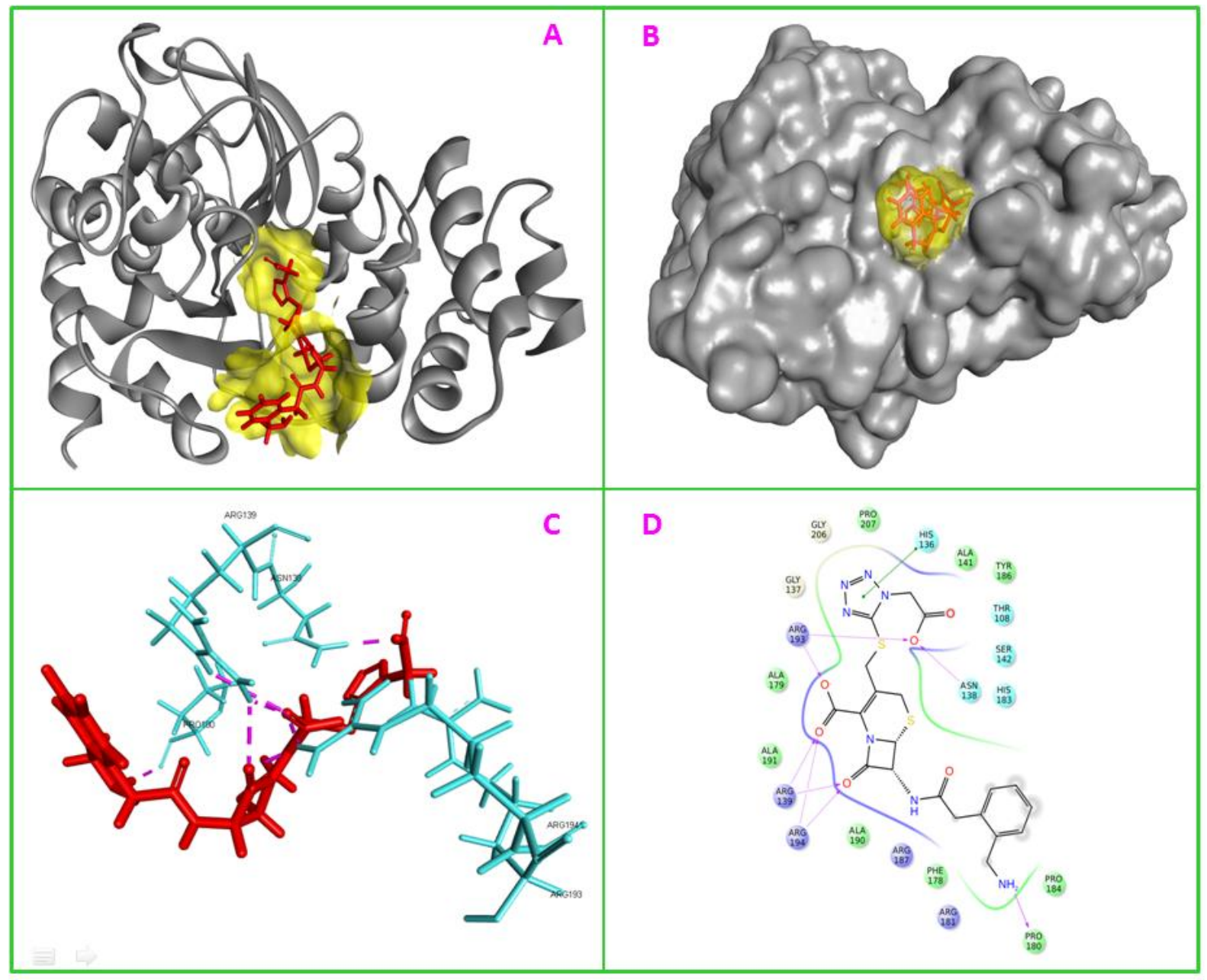

Figure 3: Binding and molecular interactions of cefpodoxime in the active site of the $\operatorname{trpD}$ of $M$. tuberculosis. Fig 3A shows the trpD in solid ribbon form (grey in color) while cefpodoxime is showed in red stick form with the active site of the protein is highlighted as yellow surface. Fig 3B shows the effective fitting of the cefpodoxime in the active site of the $\operatorname{trp} D$ (yellow surface) and cefpodoxime in stick form. Fig 3C shows the interacting amino acids of $\operatorname{trpD}$ (cyan color) by hydrogen bonds (pink color dotted lines) with the cefpodoxime (red color, stick form). Fig 3D displays the inter-molecular interactions between the trpD and cefpodoxime in two dimensional view. 


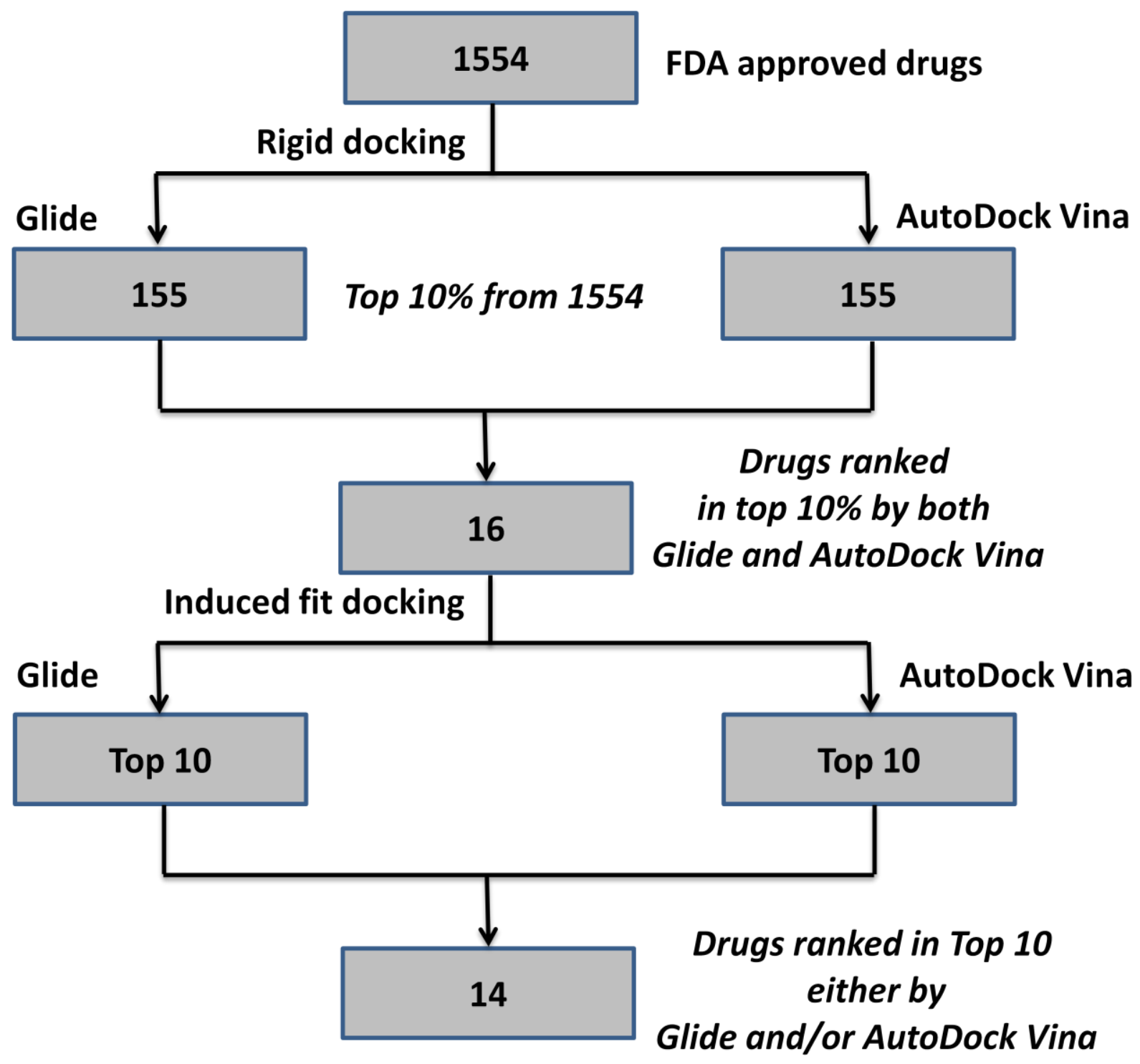

Figure4: Prioritization of 1554 known drugs using virtual screening against coaA of M. tuberculosis. 
Table 2. Prioritized drugs which show strong binding interactions with coaA of M. tuberculosis

\begin{tabular}{|c|c|c|c|c|c|c|c|c|c|}
\hline $\begin{array}{l}\text { S. } \\
\text { No }\end{array}$ & $\begin{array}{c}\text { Drug } \\
\text { Bank } \\
\text { ID } \\
\end{array}$ & $\begin{array}{l}\text { Drug } \\
\text { name }\end{array}$ & Primary use & $\begin{array}{l}\text { Glide } \\
\text { score }\end{array}$ & $\begin{array}{l}\text { Glide } \\
\text { Rank }\end{array}$ & $\begin{array}{c}\text { ADV } \\
\text { Binding } \\
\text { Affinity } \\
\end{array}$ & $\begin{array}{l}\text { ADV } \\
\text { Rank }\end{array}$ & $\begin{array}{c}\text { RMSD } \\
\left(\mathbf{A}^{\mathbf{0}}\right)\end{array}$ & $\begin{array}{l}\text { Amino acids of } \operatorname{coa} A \\
\text { interacting with drugs }\end{array}$ \\
\hline 1 & DB08995 & Diosmin & Treatment of venous disease & -13.5027 & 1 & -10.9 & 16 & 0.906 & $\begin{array}{l}\text { HIS179, TYR182, THR128, } \\
\text { TYR153, LYS103, SER104, } \\
\text { ALA100,ARG238 }\end{array}$ \\
\hline 2 & DB00694 & Daunorubicin & $\begin{array}{l}\text { For remission induction in acute } \\
\text { nonlymphocytic leukemia }\end{array}$ & -11.9108 & 2 & -11.6 & 14 & 0.898 & $\begin{array}{l}\text { HIS179, PHE254, ARG108, } \\
\text { SER104, LEU40 }\end{array}$ \\
\hline 3 & DB03147 & $\begin{array}{l}\text { Flavin adenine } \\
\text { dinucleotide }\end{array}$ & $\begin{array}{l}\text { Ophthalmic treatment for vitamin } \\
\text { B2 deficiency }\end{array}$ & -11.9008 & 3 & -16.8 & 3 & 0.901 & $\begin{array}{l}\text { HIS179, ALA100, ARG38, } \\
\text { LEU40, SER104, THR105, } \\
\text { ARG238, ASP129, LYS103, } \\
\text { VAL101, GLY102 }\end{array}$ \\
\hline 4 & DB00429 & $\begin{array}{l}\text { Carboprost } \\
\text { Tromethamine }\end{array}$ & A nonsteroidal abortifacient & -11.2632 & 4 & -12.7 & 6 & 0.896 & $\begin{array}{l}\text { ASP129, SER104, THR105, } \\
\text { ARG108, LYS103, GLY102 }\end{array}$ \\
\hline 5 & DB00471 & Montelukast & Treatment of asthma & -11.2397 & 5 & -12 & 9 & 0.909 & $\begin{array}{l}\text { TYR182, PHE254, ARG238, } \\
\text { GLY102, LYS103 }\end{array}$ \\
\hline 6 & DB00691 & Moexipril & Treat high blood pressure & -11.131 & 6 & -11.8 & 12 & 0.9 & $\begin{array}{l}\text { HIS179, ARG108, GLY41, } \\
\text { SER104, THR105, LYS103, } \\
\text { GLU42 }\end{array}$ \\
\hline 7 & DB01421 & Paromomycin & $\begin{array}{l}\text { Treatment of acute and chronic } \\
\text { intestinal amebiasis }\end{array}$ & -11.1175 & 7 & -12.9 & 5 & 0.908 & $\begin{array}{l}\text { HIS179, GLU201, ASP129, } \\
\text { SER104, GLY36 }\end{array}$ \\
\hline 8 & DB00326 & $\begin{array}{l}\text { Calcium } \\
\text { Gluceptate }\end{array}$ & Treatment of mild hypocalcemia & -9.98464 & 8 & -12 & 10 & 0.902 & $\begin{array}{l}\text { HIS179, ARG238, LYS103, } \\
\text { ALA100, LEU40, SER104, } \\
\text { GLY102 }\end{array}$ \\
\hline 9 & DB00256 & Lymecycline & $\begin{array}{l}\text { For the treatment of infections and } \\
\text { to treat acne }\end{array}$ & -9.65968 & 9 & -13 & 4 & 0.904 & HIS179, ARG108, ASP129 \\
\hline 10 & DB01328 & Cefonicid & Treatment of bacterial infections & -9.31335 & 10 & -11.8 & 13 & 0.898 & $\begin{array}{l}\text { ARG108, LEU40, SER104, } \\
\text { LYS103, GLY102, ASP129 }\end{array}$ \\
\hline 11 & DB01232 & Saquinavir & HIV protease inhibitor & -8.49036 & 12 & -17.5 & 2 & 0.911 & $\begin{array}{l}\text { HIS179, TYR153, TYR182, } \\
\text { LEU203, TYR235, ARG238, } \\
\text { LYS103, ASN277 }\end{array}$ \\
\hline 12 & DB00212 & Remikiren & $\begin{array}{l}\text { For the treatment of hypertension } \\
\text { and heart failure }\end{array}$ & -8.45254 & 13 & -12.6 & 7 & 0.906 & $\begin{array}{l}\text { HIS179, PHE254, ARG238, } \\
\text { THR127, GLU201, ARG108 }\end{array}$ \\
\hline 13 & DB06590 & $\begin{array}{l}\text { Ceftaroline } \\
\text { fosamil }\end{array}$ & Treatment of bacterial infections & -8.06396 & 14 & -19.7 & 1 & 0.904 & $\begin{array}{l}\text { TYR235, ASN277, LYS103, } \\
\text { ARG238 }\end{array}$ \\
\hline
\end{tabular}




\begin{tabular}{|c|c|c|c|c|c|c|c|c|c|}
\hline 14 & DB00950 & Fexofenadine & Treatment of hayfever & -7.32914 & 15 & -12.4 & 8 & 0.897 & $\begin{array}{l}\text { SER104, THR105, ASP129, } \\
\text { LEU40 }\end{array}$ \\
\hline PAZ & & Phosphopantothenate & & -9.76722 & & -5.8 & & 1.52 & $\begin{array}{l}\text { TYR182, TYR153, SER104, } \\
\text { LYS103, TYR235, ASN277 }\end{array}$ \\
\hline
\end{tabular}

Amino acids in bold are from the active site of the coaA. 


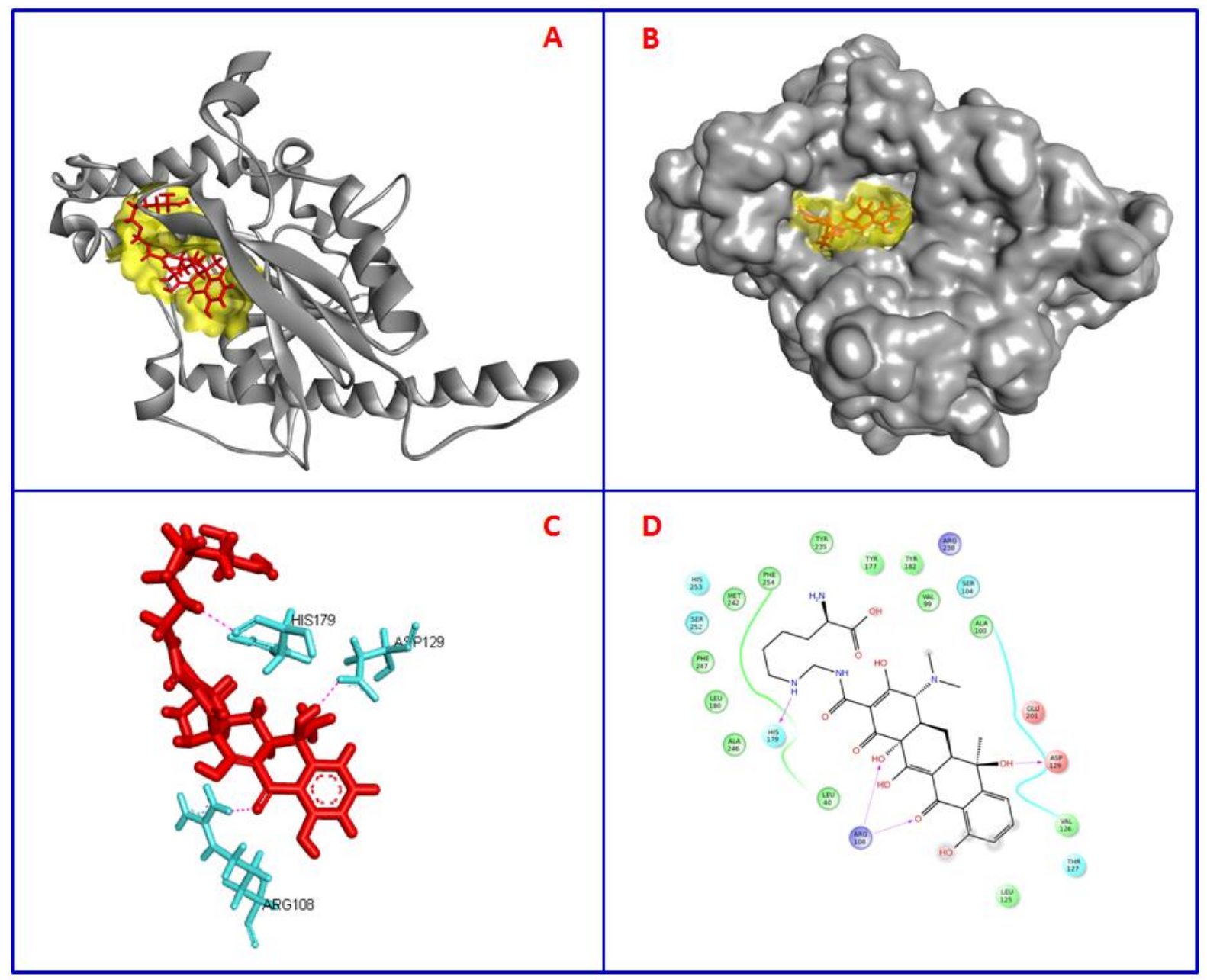

Figure 5: Binding and molecular interactions of lymecycline in the active site of the coaA of $M$. tuberculosis. Fig 5A shows the coaA in solid ribbon form (grey in color) while lymecycline is showed in red stick form with the active site of the protein is highlighted as yellow surface. Fig 5B shows the effective fitting of the lymecycline in the active site of the coaA (yellow surface). Fig 5C shows the interacting amino acids of $\operatorname{coaA}$ (cyan color) by hydrogen bonds (pink color dotted lines) with the lymecycline (red color, stick form). Fig 5D displays the inter-molecular interactions between the coaA and cefpodoxime in two dimensional view. 
Table 3: Inhibitory activity of cefpodoxime and lymecycline using luciferase reporter phage assay against $M$. tuberculosis

\begin{tabular}{|c|c|c|c|c|c|c|c|c|c|}
\hline \multirow[b]{2}{*}{ S.No. } & \multirow[b]{2}{*}{ Drug Name } & \multicolumn{2}{|c|}{$\operatorname{trpD}$} & \multicolumn{2}{|c|}{$\operatorname{coaA}$} & \multirow[b]{2}{*}{$\begin{array}{c}\text { Inhibitory } \\
\text { concentration } \\
(\mu \mathrm{g} / \mathrm{ml}) \text { and } \\
\text { percent reduction } \\
\text { of RLU against } \\
\text { M. tuberculosis } \\
\text { H37Rv }\end{array}$} & \multirow[b]{2}{*}{$\begin{array}{c}\text { Inhibitory } \\
\text { concentration } \\
(\mu \mathrm{g} / \mathrm{ml}) \text { and } \\
\text { percent reduction } \\
\text { of RLU against } \\
\text { MDR strains of } M \text {. } \\
\text { tuberculosis }\end{array}$} & \multirow[b]{2}{*}{$\begin{array}{c}\text { Synergistic } \\
\text { activity } \\
\text { concentration } \\
(\mu \mathrm{g} / \mathrm{ml}) \text { and } \\
\text { percent reduction } \\
\text { of RLU with } \\
\text { rifampin } \\
\text { against } \\
\text { M. tuberculosis } \\
\text { H37Rv }\end{array}$} & \multirow[b]{2}{*}{$\begin{array}{c}\text { Synergistic } \\
\text { activity } \\
\text { concentration } \\
(\mu \mathrm{g} / \mathrm{ml}) \text { and } \\
\text { percent reduction } \\
\text { of RLU with } \\
\text { isoniazid } \\
\text { against } \\
\text { M. tuberculosis } \\
\text { H37Rv }\end{array}$} \\
\hline & & $\begin{array}{c}\text { Rank } \\
\text { by } \\
\text { Glide }\end{array}$ & $\begin{array}{c}\text { Rank } \\
\text { by } \\
\text { ADV }\end{array}$ & $\begin{array}{c}\text { Rank } \\
\text { by } \\
\text { Glide }\end{array}$ & $\begin{array}{c}\text { Rank } \\
\text { by } \\
\text { ADV }\end{array}$ & & & & \\
\hline 1 & Cefpodoxime & 2 & 5 & NA & NA & $\begin{array}{c}20(89.46 \%), \\
50(99.72 \%) \text { and } \\
100(99.86 \%)\end{array}$ & $\begin{array}{c}20(73.86 \%) \text { and } \\
100(93.84 \%)\end{array}$ & $20(99.77 \%)$ & $20(98.39 \%)$ \\
\hline 2 & Lymecycline & 7 & 1 & 9 & 4 & $\begin{array}{c}10(93.47 \%), \\
20(95.36 \%), \\
50(99.03 \%) \text { and } \\
100(99.86 \%)\end{array}$ & $\begin{array}{c}20(51.35 \%) \text { and } \\
100(98.93 \%)\end{array}$ & $10(98.35 \%)$ & $10(99.25 \%)$ \\
\hline
\end{tabular}

Note: Percent of reduction in relative light unit (RLU) is given within brackets. 